\title{
7.4 Стратегія підвищення конкурентоспроможності підприємства
}

В сучасних умовах активізації глобалізаційних процесів основним показником оцінки економічних позицій підприємств $\epsilon$ конкурентоспроможність. Даний критерій дозволяє оцінити лідируючі позиції на ринку, виявити сильні та слабкі сторони, можливості і загрози та сформувати стратегічні напрямки розвитку.

Вчені пропонують розглядати конкурентоспроможність підприємства як мінливу величину під впливом факторів внутрішнього i зовнішнього середовища. Під конкурентоспроможною системою управління підприємством варто розуміти сукупність чинників, що реалізують місію і цілі діяльності, виходячи 3 вимог зовнішнього та навколишнього середовища та потенційних можливостей підприємства.

Система управління не може існувати поза сферою виробництва i споживання різних матеріальних цінностей. У той же час вона володіє своїми трудовими, матеріальними, енергетичними, інформаційними, фінансовими та іншими ресурсами, за допомогою яких здійснює управлінські рішення $\mathrm{i}$ організовує випуск конкурентоздатної продукції. Таким чином, конкурентоспроможність підприємства можна назвати адаптивною системою, так як вона пов'язана 3 мінливим ринковим середовищем і зростаючими потребами суспільства.

Ступінь конкурентоспроможності підприємства, іншими словами, характер його конкурентної переваги у порівнянні з іншими підприємствами, перш за все, залежить від того, як воно організовує і виконує всі види своєї діяльності.

В табл. 7.4.1-7.4.2 наведена класифікація рівнів управління конкурентоспроможності 3 позиції двох факторів: залежно від масштабів конкуренції та рівня управління процесами підприємства. 
Таблиця 7.4.1

Рівні управління конкурентоспроможністю підприємства залежно від масштабності конкуренції

\begin{tabular}{|c|c|c|}
\hline $\begin{array}{l}\text { Рівень управління } \\
\text { конкурентоздатні } \\
\text { стю підприємства }\end{array}$ & $\begin{array}{c}\text { Основні об'єкти } \\
\text { управління }\end{array}$ & Основні результати управління \\
\hline 1 & 2 & 3 \\
\hline Нанорівень & $\begin{array}{l}\text { Конкурентоспроможність } \\
\text { продукції підприємства }\end{array}$ & $\begin{array}{lr}\text { Прибутковість, } & \text { платоспроможність, } \\
\text { забезпечення } & \text { конкурентного } \\
\text { маневрування та ін. } & \end{array}$ \\
\hline \multirow[t]{2}{*}{ Мікрорівень } & $\begin{array}{l}\text { Конкурентні переваги } \\
\text { підприємства та } \\
\text { конкурентоспроможність } \\
\text { підприємства }\end{array}$ & 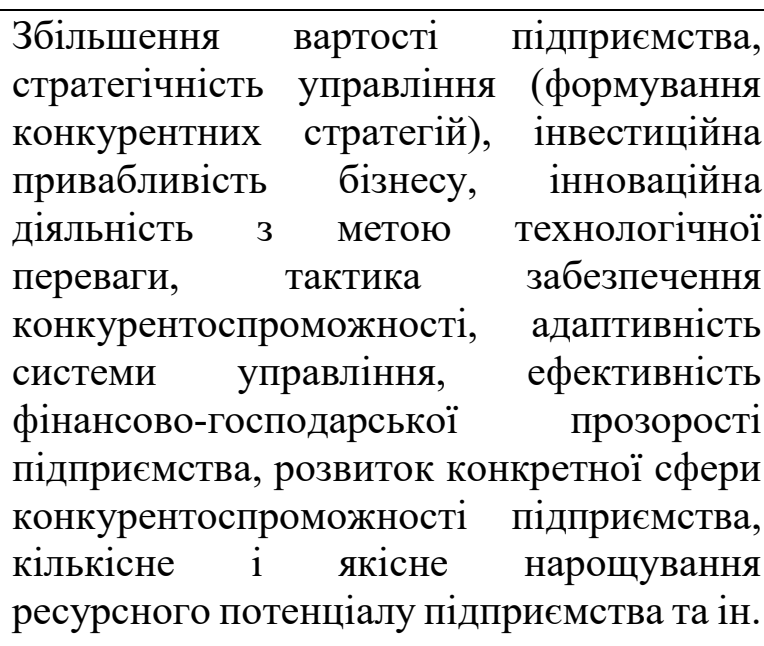 \\
\hline & $\begin{array}{l}\text { Конкурентоспроможність } \\
\text { диверсифікації мережевих } \\
\text { структур } \quad \text { (кластери, } \\
\text { технопарки і т.п.) }\end{array}$ & $\begin{array}{l}\text { Конкурентні та партнерські відносини } \\
\text { підприємства } 3 \text { іншими підприємствами, } \\
\text { приватними підприємцями, розвиток } \\
\text { кластерних структур як інструменту } \\
\text { захисту вітчизняних товаровиробників і } \\
\text { збереження його ефективності діяльності } \\
\text { та конкурентоспроможності }\end{array}$ \\
\hline \multirow[t]{2}{*}{ Мезорівень } & $\begin{array}{l}\text { Конкурентоспроможність } \\
\text { галузі }\end{array}$ & $\begin{array}{l}\text { Здатність підприємств створювати обсяг } \\
\text { доданої вартості конкретної галузі, } \\
\text { підвищення ефективності використання } \\
\text { факторів виробництва, забезпечення } \\
\text { інвестиційної привабливості галузі, } \\
\text { освоєння нових ринків підприємствами } \\
\text { галузі }\end{array}$ \\
\hline & $\begin{array}{l}\text { Конкурентоспроможність } \\
\text { регіону, міжрегіональних і } \\
\text { міжгалузевих об'єднань }\end{array}$ & $\begin{array}{l}\text { Підвищення } \\
\text { підприємстввності діяльності } \\
\text { систем }\end{array}$ \\
\hline
\end{tabular}


Продовження табл. 7.4.1

\begin{tabular}{|c|c|c|}
\hline 1 & 2 & 3 \\
\hline Макрорівень & $\begin{array}{l}\text { Конкурентоспроможність } \\
\text { країни }\end{array}$ & $\begin{array}{l}\text { Здатність країни конкурувати } 3 \text { іншими } \\
\text { країнами, рівень ії комплексного } \\
\text { розвитку, яке визначається якістю життя } \\
\text { населення, збільшення частки продукції } \\
\text { нових високотехнологічних } \\
\text { наукомістких галузей у валовому } \\
\text { внутрішньому продукті, якістю товарів, } \\
\text { робіт і послуг, ступенем інтегрованості } \\
\text { країни у світове співтовариство, зрілістю } \\
\text { політичної та економічної систем і ін. }\end{array}$ \\
\hline Мегарівень & $\begin{array}{l}\text { Міжнародна конкуренція, } \\
\text { що носить } \\
\text { інтернаціональний } \\
\text { характер }\end{array}$ & $\begin{array}{l}\text { Розвиток діяльності найбільших ТНК, } \\
\text { крупних експортерів продукції } \\
\text { імпортерів сировини, обладнання та ін. }\end{array}$ \\
\hline
\end{tabular}

Таблиця 7.4.2

Рівні управління конкурентоспроможністю підприємства залежно від рівня управління процесами підприємства

\begin{tabular}{|c|c|c|}
\hline $\begin{array}{c}\text { Рівень управління } \\
\text { конкурентоздатністю } \\
\text { підприємства } \\
\end{array}$ & $\begin{array}{c}\text { Основні об'єкти } \\
\text { управління }\end{array}$ & Основні результати управління \\
\hline Оперативний & $\begin{array}{l}\text { Конкурентоспроможні } \\
\text { сть } \quad \text { продукції } \\
\text { підприємства } \\
\end{array}$ & $\begin{array}{lr}\text { Прибутковість, } & \text { платоспроможність, } \\
\text { забезпечення } & \text { конкурентного } \\
\text { маневрування та ін. } & \\
\end{array}$ \\
\hline Тактичний & $\begin{array}{l}\text { Конкурентні переваги } \\
\text { підприємства за } \\
\text { тактичний } \\
\text { конкурентний період }\end{array}$ & $\begin{array}{lc}\text { Tактика } & \text { забезпечення } \\
\text { конкурентоспроможності, } & \text { адаптивність } \\
\text { системи управління, } & \text { ефективність } \\
\text { фінансово-господарської } & \text { прозорості } \\
\text { підприємства, керованість бізнесу }\end{array}$ \\
\hline Стратегічний & $\begin{array}{l}\text { Конкурентоспроможні } \\
\text { сть підприємства }\end{array}$ & $\begin{array}{llr}\text { Збільшення } & \text { вартості } & \text { підприємства, } \\
\text { стратегічність } & \text { управління } & \text { (формування } \\
\text { конкурентних } & \text { стратегій), інвестиційна } \\
\text { привабливість } & \text { бізнесу, } \\
\text { діяльність } 3 & \text { метою } & \text { техноцоційна } \\
\text { переваги та ін. } & & \end{array}$ \\
\hline
\end{tabular}

Досягнення конкурентоспроможності підприємства неможливе без впровадження системних інновацій, що є запорукою їх успішного розвитку.

Під стратегічної стійкістю конкурентних переваг підприємства розуміється здатність конкурентних переваг забезпечувати стратегічну технологічну конкурентоздатність виробничої системи при мінливому впливі зовнішнього і 
внутрішнього середовища.

Для довгострокового розвитку підприємства на основі процесу формування i / або підвищення його конкурентоспроможності необхідно конкретизувати складові (мал. 7.4.1), від яких найбільшою мірою залежить розглянута категорія.

В довгостроковому періоді підвищення стратегічної технологічної конкурентоспроможності можливе за рахунок вирішення наступних завдань:

- реорганізації виробничих процесів і освоєння нових технологій;

- підвищення рівня розвитку науково-дослідних і дослідноконструкторських робіт;

- підвищення якості продукції, що виробляється;

- підвищення ефективності за рахунок змін реорганізації мотиваційноконтрольних аспектів функціональної діяльності персоналу підприємства;

- підвищення якості навчання і залучення кадрів, особливо виробничого персоналу і менеджменту у виробничій системі підприємства;

- зміни підходів до управління підприємством, зокрема, оцінки поточного рівня і перспектив розвитку підприємства.

В якості основи для формування конкурентоспроможності підприємства як ключового інноваційного чинника його довгострокового розвитку, пропонується використовувати такі основні складові:

1) інноваційні технології основних та допоміжних процесів виробництва продукції;

2) інноваційні технології управління персоналом, обслуговуючим виробництво продукції;

3) інноваційні технології інфраструктурних зв'язків підприємства.

Деталізуючи представлену на малюнку 1 схему, необхідно зауважити, що під інноваційно-конкурентними технологіями процесів розуміються нові методологічні підходи організації виробничого процесу на підприємстві, що включають в себе інноваційні технології використання економічних ресурсів усіх видів, а також інноваційні технології засобів праці та інтелектуальні технології. 


\begin{tabular}{|c|c|c|}
\hline \multicolumn{3}{|c|}{ Стратегічна конкурентоспроможність підприємства } \\
\hline$\nabla$ & $\downarrow$ & 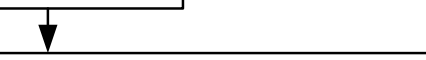 \\
\hline Технологія & Персонал & Інфраструктура \\
\hline$\downarrow$ & $\nabla$ & $\nabla$ \\
\hline $\begin{array}{l}\text { 1. Удосконалення та } \\
\text { інтенсифікація основних } \\
\text { виробничих процесів. } \\
\text { 2. Удосконалення та } \\
\text { інтенсифікація } \\
\text { допоміжних виробничих } \\
\text { процесів } \\
\text { 3. Скорочення тривалості } \\
\text { виробничого циклу. } \\
\text { 4. Раціоналізація системи } \\
\text { матеріально-технічного } \\
\text { забезпечення }\end{array}$ & $\begin{array}{l}\text { 1) Ліквідація різниці в планах при } \\
\text { задоволенні потреби в людських } \\
\text { ресурсах. } \\
\text { 2) Оптимальна величина набору } \\
\text { персоналу залежно від потреб. } \\
\text { 3) Застосування мотиваційних } \\
\text { заходів у вигляді коригування } \\
\text { розміру заробітної плати і } \\
\text { компенсацій. } \\
\text { 4) Профорієнтація та адаптація } \\
\text { управлінського і управлінсько- } \\
\text { технічного персоналу, які } \\
\text { обслуговують виробничі процеси } \\
\text { підприємства }\end{array}$ & $\begin{array}{l}1 \text { ) Зміни } \\
\text { інфраструктурних } \\
\text { зв'язків у вигляді } \\
\text { зміни розвитку } \\
\text { процесів інтеграції } \\
\text { підприємства } \\
\text { 2) Оптимізація } \\
\text { логістичної складової } \\
\text { інфраструктурних } \\
\text { зав'язків } \\
\text { підприємства. }\end{array}$ \\
\hline
\end{tabular}

Малюнок 7.4.1. Складові формування стратегічної технологічної конкурентоспроможності підприємства

Розглянемо кожну із складових процесу формування конкурентоспроможності підприємства докладніше.

1. Подолання виявленої різниці між фактичним і гранично можливим результатом виробничого процесу, рівнем використання технічного оснащення виробничих систем, що може бути досягнуте за рахунок удосконалення та інтенсифікації основних виробничих технологічних процесів підприємства (що забезпечить підвищення продуктивності праці і призведе до зниження собівартості виробленої продукції) шляхом:

1.1 Удосконалення виробництва і його організації в кількісних і якісних показниках; ліквідації недостатності комп'ютеризації виробництва, наприклад, впровадження більшої кількості мікропроцесів, кожен з яких орієнтований на виконання не однієї, а декількох завдань.

1.2 Удосконалення та інтенсифікації допоміжних виробничо-технологічних процесів підприємства (що забезпечить підвищення продуктивності праці i, призведе до зниження собівартості виробленої продукції) за рахунок: 
- розробки та впровадження вдосконалених способів використання контрольно-вимірювальних та інших засобів визначення якості і правильності роботи обладнання;

- розробки та впровадження удосконалених методів діагностики і усунення несправностей, регулювання, налагодження, настройки машин, механізмів, приладів, інших технічних пристроїв і об'єктів;

- дослідженнями i їх аналізом кількісних i якісних залежностей між величинами, параметрами, характеристиками технічних об'єктів.

1.3 Скорочення тривалості виробничого циклу (що забезпечить збільшення продуктивності праці і, в наслідку, зниження собівартості виробленої продукції) шляхом:

- організації ритмічної роботи відповідно до графіка;

- ліквідації простоїв в процесах обробки сировини і напівфабрикатів;

- переходом від періодичних процесів виробництві продукції до безперервних;

- раціоналізації розміщення високопродуктивного обладнання;

- раціоналізації системи планово-попереджувального ремонту обладнання;

- комплексної автоматизації та комп'ютеризації виробництва продукції;

- безперервністю транспортних операцій, збільшенням швидкостей переміщення предметів праці;

1.4. Раціоналізацією матеріально-технічного обладнання (задоволення виявленої потреби підприємства в матеріальних ресурсах рекомендується проводити на основі балансу МТО підприємства при обліку залишків i внутрішніх джерел забезпечення), тобто обсягу необхідних матеріальних ресурсів, необхідних:

- для впровадження нової техніки;

- для виготовлення оснащення та інструменту;

- на експлуатаційні і технологічні потреби;

- на створення необхідного заділу незавершеного виробництва;

- на утворення перехідних запасів. 
2. Розвитку підприємства за рахунок подолання різниці між існуючим i максимально можливим ефектом діяльності персоналу підприємства, що обслуговує технологічний і управлінсько-технологічний процеси, що може бути досягнуто за рахунок:

2.1 Ліквідації різниці в планах при задоволенні потреби в людських pecypcax.

2.2 Оптимальної величини набору персоналу в залежності від визначеної різниці.

2.3 Застосуванні мотиваційних заходів у вигляді коригування заробітної плати та компенсацій: зміна структури заробітної плати; зміна в розробках компенсацій і пільг з метою мотивації персоналу при виявленні необхідності і можливостей підприємства.

2.4 Проведення профорієнтаційних заходів та адаптація управлінського та управлінсько-технічного персоналу, які обслуговують виробничі процеси підприємства, при виявленні необхідності і можливостей підприємства, шляхом:

- розробки та впровадження програм навчання персоналу;

- розробки та впровадження скоригованих методів просування працівників на інші посади зі зміною ступеня персоніфікованої відповідальності;

- розробки та впровадження програм, спрямованих на необхідний розвиток здібностей та управлінського персоналу і т.д.

3. Розвитком підприємства за рахунок подолання різниці між потенційно ефективною кількістю інфраструктурних зв'язків підприємства та їх фактичною кількістю, в тому числі логістичних, що може бути досягнуто за рахунок:

3.1 Зміни підходів до управління підприємством, зокрема, оцінки поточного рівня і перспектив розвитку з точки конфігурації інфраструктурних зв'язків, тобто у вигляді зміни розвитку процесів інтеграції підприємства 3 різними агентами економічного середовища.

3.2 Оптимізації логістичної складової інфраструктурних зв'язків підприємства в розмірі виявлених необхідних змін, шляхом:

- оптимізації транспортних витрат (спрямованих на коригування виявленої 
різниці шляхом мінімізації транспортних витрат у вигляді раціоналізації транспортних і пов'язаних потоків;

- оптимізації логістики постачання;

- оптимізації складських витрат;

- оптимізації трансакційних витрат.

Таким чином, стратегічну конкурентоспроможність підприємства варто розглядати як узагальнену характери існуючого і потенційно можливого рівнів розвитку в конкурентному середовищі за рахунок виділення груп ресурсів, які використовуються не повною мірою, і можливостей оптимізації їх використання в довгостроковій перспективі за допомогою впровадження комплексу концептуально нових методик мобілізації резервів підприємства. 